\title{
Between flowers and fears: the new coronavirus pandemic (COVID-19) and the flower retail trade
}

\author{
Adilson Anacleto $^{1^{*}}$ (), Anna Paula de Araújo Bornancin ${ }^{1}[$, \\ Silas Hallel Camilo Mendes ${ }^{1}$ (), Luciane Scheuer $^{1}$ (1)
}

${ }^{1}$ Universidade Estadual do Paraná, Campus de Paranaguá, Paranaguá-PR, Brazil.

\begin{abstract}
In order to support a better understanding of the current scenario of the crisis installed by the New Coronavirus (SARS-CoV-2: COVID-19) in the flower retail trade, it is presented a descriptive exploratory research carried out between April and May 2020 with 30 flower shop managers located in the Southern region of Brazil. The results showed that the most significant impacts were the drop in the number of customers, which reduced the company's income when compared to the values sold before the pandemic, and that the pandemic scenario generated a $45.3 \%$ reduction in financial transactions on average. Among the flower shops in this survey, $70 \%$ of flower shops were closed for an average of 21.4 days, when they were reopened with restrictions on attendance related to hours or the number of people inside the stores. The e-commerce and social media were the main tools to confront this situation, and the most used Apps were WhatsApp and Instagram. But other actions such as discounting on purchases by quantity, free delivery and marketing in the surrounding were also registered. Among the possible complementary actions in order to face this crisis and which can have positive effects, it is highlighted the online courses directed to the trade of gardening kits, the adoption of the Just In Time (JIT) methodology that can result in partnerships with local producers in order to reduce inventory costs and purchase prices, and the organization of collective purchasing groups to bargain prices with wholesalers, as well as the reduction of transportation and operational costs at Veiling in Holambra.
\end{abstract}

Keywords: economy, flower shops, ornamental horticulture, ornamental plants, social isolation.

\section{Resumo}

Entre flores e temores: a pandemia do novo coronavírus (COVID-19) e o comércio varejista de flores

Visando a subsidiar uma melhor compreensão do cenário da crise instalada pelo novo coronavírus (SARS-CoV-2: COVID-19) no mercado varejista de flores, apresenta-se resultado de pesquisa exploratória descritiva realizada entre abril e maio de 2020 junto a 30 gestores de floriculturas localizadas na região sul do Brasil. Os resultados evidenciaram que os impactos mais significativos foram a queda no número de clientes, o que reduziu o faturamento quando comparado com os valores comercializados antes da pandemia, gerando uma redução na movimentação financeira de 45,3\% em média. Das floriculturas pesquisadas, 70\% ficaram fechadas em média 21,4 dias e quando foram reabertas, se deu com restrições no atendimento relativo ao horário ou controle do número de pessoas nas lojas. O uso do e-comerce e mídias sociais foram as principais ações de enfrentamento comercial na retomada das vendas, sendo os aplicativos mais usados o WhatsApp ${ }^{\circledR}$ e Instagram ${ }^{\circledR}$. No entanto outras ações como desconto nas compras por quantidade, entrega grátis e marketing nas regiões de entorno das lojas também foram registrados. Entre as possíveis ações tomadas no enfrentamento da crise gerada pelo novo coronavírus e que pode vir a apresentar efeitos positivos, se destaca a oferta de cursos online direcionado ao comercio de kits de jardinagem, a adoção da metodologia just in time que poderá resultar na parceria com produtores locais para reduzir os custos de estoque e preço de compra, a organização de grupos de compras coletivas para barganhar preço junto aos atacadistas, bem como, a redução de custos de transporte e operacionalização no Veiling de Holambra.

Palavras-Chave: economia, floricultura, horticultura ornamental, plantas ornamentais, isolamento social.

\footnotetext{
*Corresponding author: adilson.anacleto@unesapr.edu.br
} 


\section{Introduction}

At the end of 2019, the world was marked by the beginning of a viral outbreak, which initially spread throughout China, and then quickly moved to other countries where it also showed lethal behavior, this infectious agent was called the new SARS-CoV-2 Coronavirus that causes the disease called COVID-19, an English acronym for Coronavirus Disease 2019, which still in the first month of 2020 gained worldwide pandemic status (Croda and Garcia, 2020; OMS, 2020).

According to Aquino (2020), the COVID-19 has a high rate of transmission among people and there are no vaccines or drugs able to guarantee the cure or even minimizing the effects on those infected. This fact has promoted that nonpharmacological and prophylactic measures, essential to reduce the risks of transmission were taken into account such as the social isolation, that was considered the main alternative in combating the proliferation of the disease and reducing the lethality of the pandemic in the world (Aquino, 2020; OMS, 2020).

The social isolation, also called quarantine, was accepted by most countries on the planet and immediately generated impacts, in addition to human health, also on the economy with the drop in consumption, in incomegenerating activities, reduction of the production system, temporary closure of commercial establishments and the unemployment, these reactions caused by the pandemic were initially overwhelming in Europe, and currently they are in practically all countries around the world (Bezerra, 2020; Tonelli, 2020).

The first case of COVID-19 in Brazil, according to Croda and Garcia (2020), was confirmed in February 2020, and the Ministério da Saúde (2020) have already recommended prophylaxis measures from the end of March 2020 , similarly what was occurring in other countries. The Ministry of Health also adopted measures of social isolation, when it was decreed the closure of establishments classified as not essential to human survival.

Among the establishments classified as non-essential, the flower shops were included. From April 2020 they had their commercial activities restricted in various regions of Brazil, operating with reduced time, or were forced to close their doors to the consumer. According to Guarizzo (2020), the flower production and trade sector was one of the most affected in Brazil during the quarantine. In addition to the loss of daily sales, there was suspension of celebratory and funeral activities where flowers are very used. The sector had to discard thousands of flowers, which affected not only trade, but also the continuity of flower production in hundreds of rural properties and put at risk the survival of more than eighteen thousand establishments linked to the flower trade in Brazil.

Thus, in order to support a better understanding of this current scenario installed by the COVID-19 in the flower retail trade, this research sought to analyze the impacts of the crisis on flower shops in terms of commercial recovery and their conditions to face the problems after the start of the pandemic.

\section{Material and Methods}

Between April and May 2020, a descriptive exploratory research was conducted with 30 owners or managers of flower shops in 20 cities from Southern region of Brazil, and the choice was made by accessibility, and their predisposition to participate in the study. This research is considered qualitative due to the fact that its aim was to collect data based on the self-perception of the flower shops managers interviewed without worrying about the use of statistical techniques, in order to analyze their perception on the current crisis scenario.

A semi-structured interview, with a pre-elaborated question script, was applied as the data collection instrument (Vergara, 2015). The interview was completed by 30 managers using an electronic questionnaire made available to the respondents after previous contact by phone and e-mail. Initially, the respondents answered questions about the socioeconomic and historical profile of their flower shops, as well as the kinds of flowers most commercialized before and after the New Coronavirus (COVID-19) pandemic.

Subsequently, the managers answered questions about the impacts of the pandemic caused by the New Coronavirus (COVID 19) on psychological aspects, the last step of the data collection was related to the marketing aspects and about actions that could be carried out by the flower retail market in relation to the pandemic. After finishing the data collection according to what was proposed by Vergara (2015), an interpretative analysis was adopted, performed using the data triangulation technique with similar groupings, with the focus on classifying elements that could be perceived as similar or relatively homogeneous based on the set of researched questions. It was sought to homogenize the possible objects within the groups and simultaneously maximize the heterogeneity among the investigated group.

\section{Results}

The study revealed that among the interviewees there was the predominance of women $(n=64 \%)$ in the management of flower shops, and these establishments was on average 15.7 years old, therefore they can be considered consolidated enterprises in the market. Regarding marital status, married people were the vast majority $(n=77.4 \%)$, followed by people who were formally in a stable union $(\mathrm{n}=13.6 \%)$ and there were in equal percentage single managers $(n=4.5 \%)$ and divorced managers $(n=4.5 \%)$. The average age was 42.09 years old, and the schooling was divided into three groups, the of them $(n=54 \%)$ had high school education, followed by who had graduation in college $(\mathrm{n}=41.5 \%)$ and with postgraduate studies ( $\mathrm{n}$ $=4.5 \%$ ), however schooling did not reveal variations in relation to age, marital status and education in terms of problems or actions to face the New Coronavirus crisis.

Related to the people who were effectively in the activities, an average of 3.08 people per store were working, 
being the majority of the workforce belonging to the family, and the majority of the flower shops was classified as microenterprises $(n=66.6 \%)$, followed by those classified as individual microentrepreneurs $(n=24.4 \%)$ and the other ones as small companies $(n=9 \%)$.

The field research showed that regardless of the company's type classification, 70\% of flower shops were closed by the pandemic, and in these cases the stores were closed on average 21.4 days, when they were then reopened with the government authorization. After the opening, economic impacts were registered for most stores, and the most significant impact was the drop in the number of customers, and consequently the result was the drop of sales and profitability. And related to social aspects, the risk of contagion due to the lack of prophylaxis from the customers was the most recurrent situation (Figure 1).

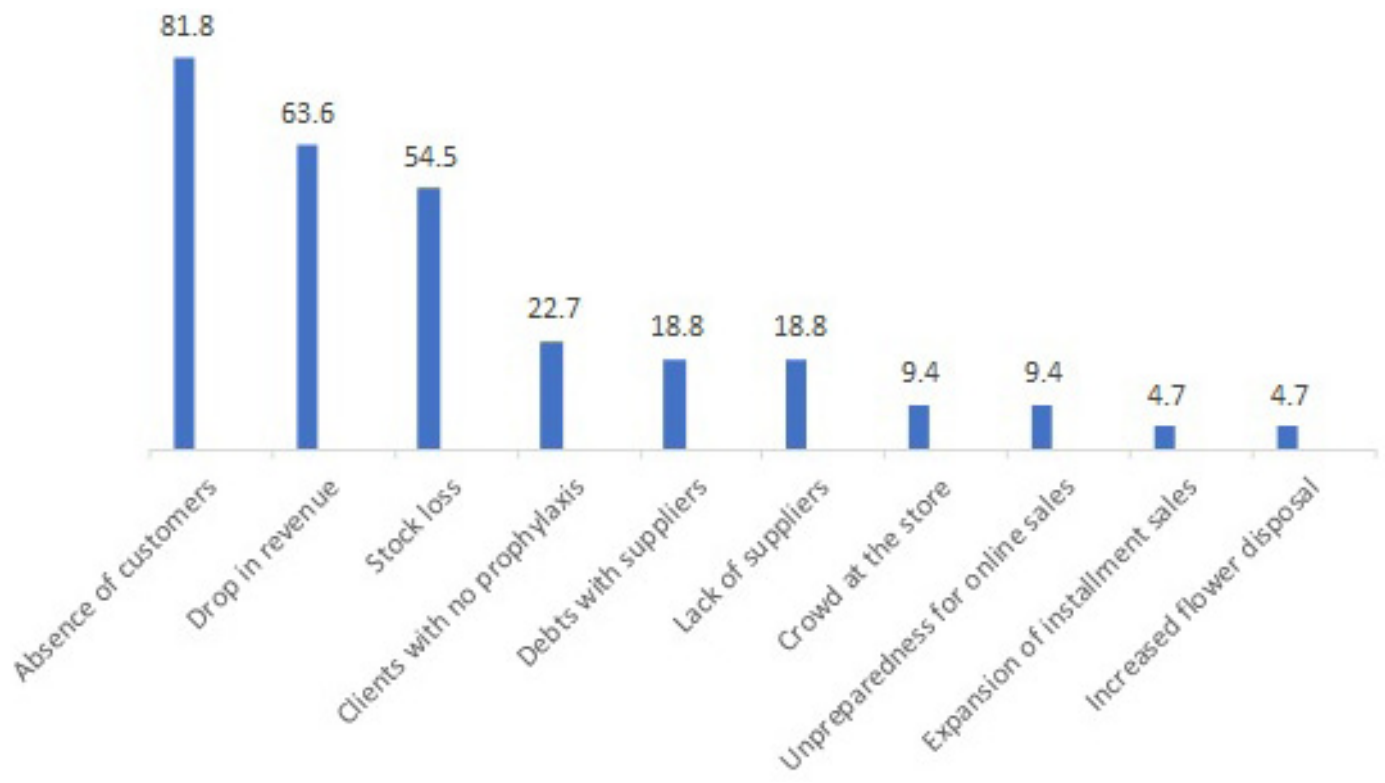

Figure 1. Main problems in the self-perception of small business managers after the beginning of the COVID-19 crisis $(\mathrm{n}=30)$. Multiple answers questions $(\%)$

Only two of the interviewees had to access bank and/ or family loans to honor their financial commitments and debts, and in only one case it was necessary fire an employee.

Regarding the preparation to face the period of pandemic, significant part of the interviewees $(n=40 \%)$ took some kind of online training or course that could help them in their commercial activities in order to change the situation of falling profitability. Among the most accessed courses, topics related to online flower sales and project management in crisis periods have been chosen.

Considering the drop in revenue, this condition was reported by $73 \%$ of the interviewees, with a reduction of the financial flow by an average of $45.3 \%$ of the amounts collected when compared to the months in the previous period to the beginning of the pandemic. To this group it was necessary the urgent establishment of commercial actions in order to face the drop in sales caused by the pandemic. All the interviewees have been reported the use of e-commerce by social media as the main action to have the resumption of sales, additionally to this action, the discount in products for customers, free delivery and marketing in the surrounding neighborhoods where the flower shops were located, were also registered as a way of expanding flower sales (Figure 2). 


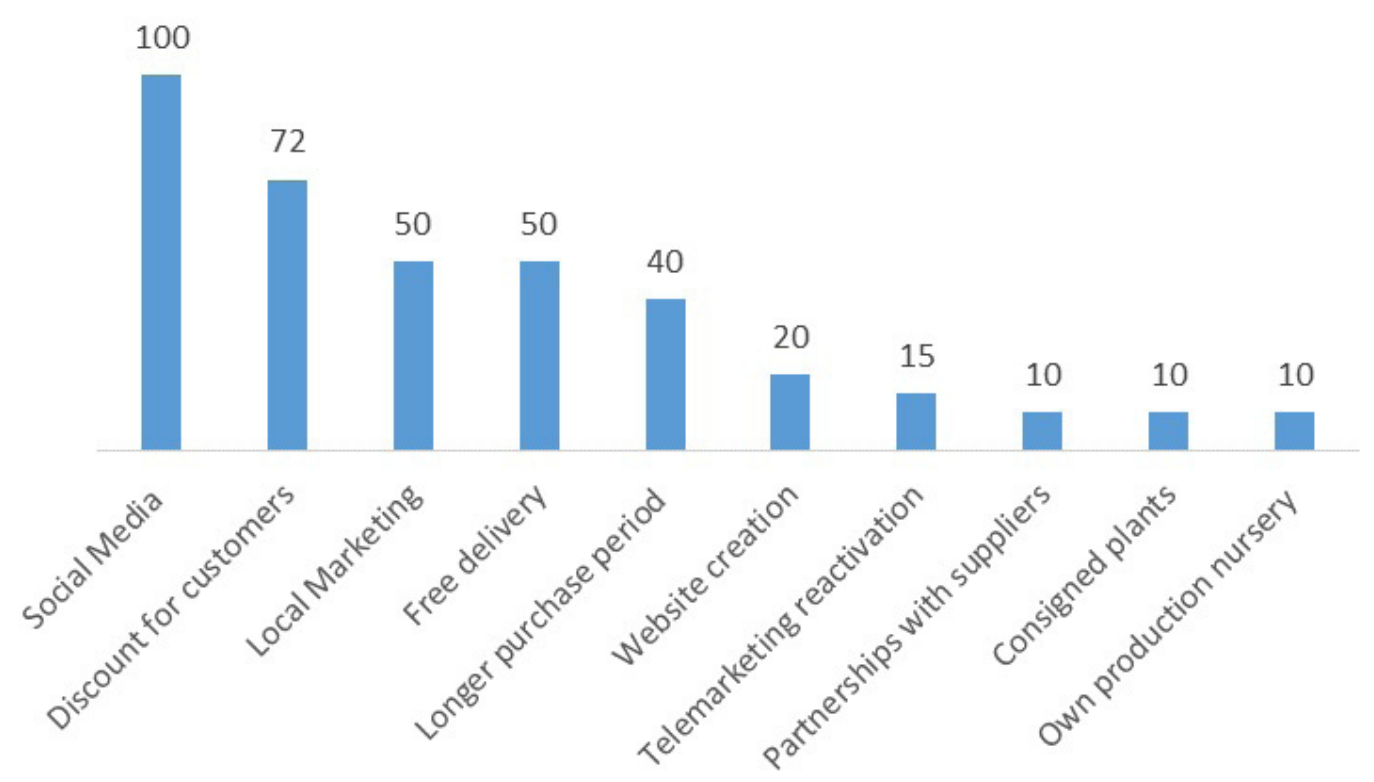

Figure 2. Main commercial actions in order to face the drop in revenue adopted by the flower shops (\%), 60 days after the beginning of the COVID 19 pandemic quarantine $(\mathrm{n}=30)$. Multiple answers questions $(\%)$

The way of commercializing the products has undergone profound changes in the flower retail trade process and with the growing relevance of social media in this market came with it the flower delivery directly to the customers' houses, but different from the purchase to give as a gift, the acquisition was for own use. In this case all the respondents used Apps with greater adherence to WhatsApp and Instagram (Figure 3).

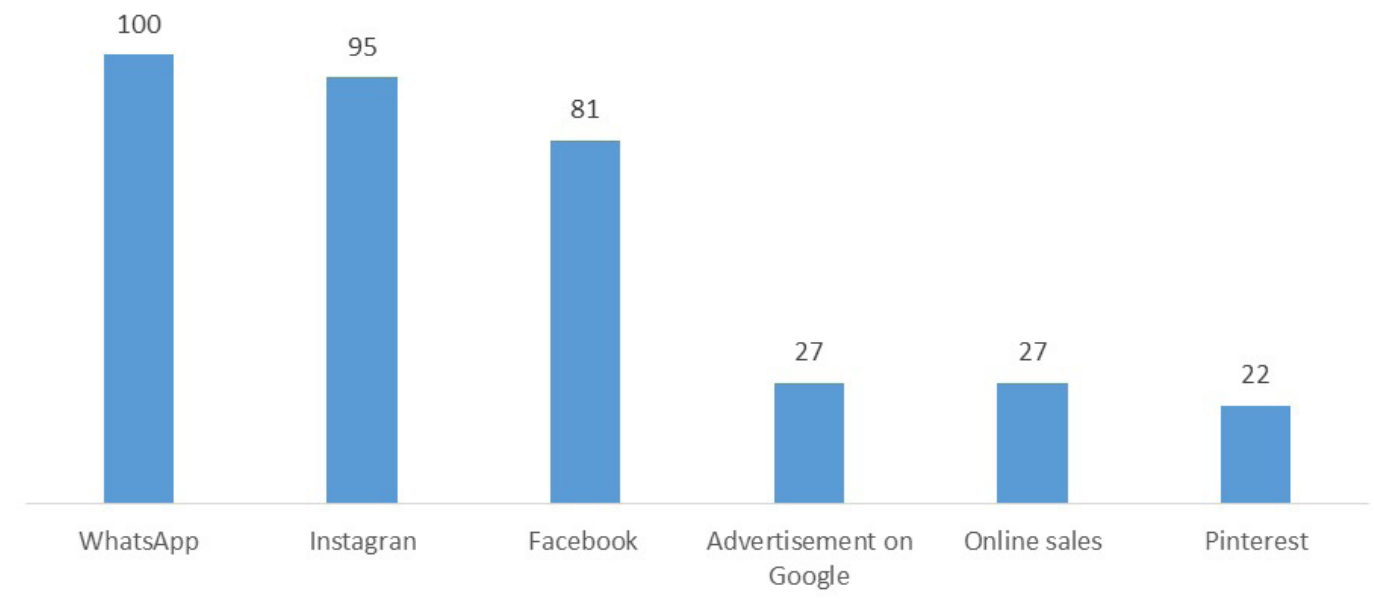

Figure 3. Main marketing channels adopted by the flower shops (\%), 60 days after the beginning of the COVID 19 quarantine pandemic $(\mathrm{n}=30)$. Multiple answers questions $(\%)$

In relation to the types of flowers sold after starting the COVID 19 pandemic, there were no reports of changes in purchasing behavior for both for own use and gift giving, with roses and orchids remaining, in a general context, as the group of species most sought by the consumers, which coincides with was reported by Junqueira and Peetz (2017), however there was an increase $(n=16 \%)$ in sales of flowers for gardening.
The study also revealed that $27 \%$ of respondents have already sold flowers online with the help of social medias, and in these cases, there was no drop in the revenue or sales. There were two reports of sales increasing, probably due to the fact that the other stores with no e-commerce tradition were closed or operating under service restrictions. It was also observed among the group with online sales domain, that the Pinterest tool was the second tool most used, the 
first one was Instagram when compared to the group of respondents who had reduction in sales, they reported the use of this media to sell better elaborated products with greater purchasing value such as floral arrangements and cache-pots.

\section{Discussion}

The impacts of the pandemic caused several changes in the commercial sector of flowers and ornamental plants shops, which required adaptability to reduce losses. However, the actions taken were not yet sufficient to have the pre-crisis levels, so this situation demands that the level of articulation and the development of commercial strategies have greater commercial power than those established after the beginning of the pandemic crisis.

Despite the immediate answer to the sharp drop ( $\mathrm{n}=$ $45.3 \%$ ) in sales and the fast adaptation to the new scenario imposed, especially with the use of e-commerce and social medias, some commercial tools could be better exploited by flower retailers. The trade of flowers is not classified as an essential item, so in a scenario where a significant part of the population had reduction in the income (Anacleto and Prazeres, 2020), directing commercial actions to a higher income public may be efficient, and social medias such as Pinterest, which currently has around 250 million of users in the world and the profile of people are characterized by the search for products different from the regular ones, can represent a relevant alternative. The proposition coincides with the data of this study which says that the use of this media to sell better elaborated products with greater purchasing value, such as floral arrangements and cachepots, is efficient. So regionally, Pinterest may become a good tool in order to show the products targeted at higher income people.

The implementation of online training courses by the retailers themselves with the use of regional ornamental flowers and plants, apparently may become an important argument in the creation of a new model of relationship with the customers. This proposition gains relevance as the study revealed that there was a growing demand for gardening inputs, that is, a variable in consumers' behavior due to isolation, redirecting their demand and their priorities. In this pandemic scenario, given the impacts on people's physical and mental health, some alternatives that are reducing the damage caused by the social isolation emerge, in this sense Feitosa et al. (2014) describe that horticulture can be a tool for psychosocial therapy because it is based on involving individuals with nature, and this relationship may provide relaxation and may reduce anxiety, making people peaceful.

The proposition is also endorsed by Komatsu and Menezes Filho (2020) who said that the option for distance activities has been the immediate solution for small companies, but it is important to mention that the offer of gardening and online cultivation courses by themselves, does not guarantee the effectiveness of profits. It is necessary the activity to be anchored in relationship marketing and in expanding the mix of floriculture products offered to the consumer, such as flower trays with different species and gardening kits, flowers that also involve organic products with no risks for families' health and fertilizers, pots and other products. The guidelines on how and when to plant and how to maintain the flowers can be a direct channel of communication between the retailers and consumers, which can facilitate the commercial flow of flower shops. In this way, the offer of courses was already practiced by some interviewees $(n=27 \%)$, who already are using this model of action efficiently to attract consumers.

Similar actions to the proposal involve relationship marketing, and with the help of social medias it can involve the client in the decisions about what courses they would like to participate and what species they would like to learn about cultivating. According to Bornancin (2018) the adoption of practices like this, transcends the commercial relationship, allowing evaluations of the products they have consumed, and can generate a virtuous cycle, where the customer actively participates in the day by day of the flower shop, and in this collaborative system, the retailer may communicate the consumer's wishes to the flower producers who can satisfy the consumer with fresh flowers and therefore more durable, facilitating customer loyalty even in adverse times.

Actions related to projects management should also be considered as priorities in this new scenario, as an example the adoption of the concepts like Just in Time method of management, this system can reduce the flower shop operating costs, buying only what is necessary to serve the customer.

According to Abilio (2020), nowadays the information technologies generates agility to the production chain processes, which promote the reduction of financial capital and avoid high inventory costs. This way, the administration makes its own effective productivity, controlling the stages of work and the trade shows what is possible to outsource, establishing partnerships, transferring risks and costs of time control and work execution, with no loss of productivity. Thus, the Just in Time method could be used in the flower retail trade in the New Coronavirus crisis. According to Guimaraes and Falsarella (2008), Just in Time is a management methodology that seeks to meet the needs of the customers in the shortest possible time, ensuring quality and working with minimum stock, in order to have the organization integration, through the simplest process such as partnerships and buying just what is sold, to allow the process of change, directed by the needs of customers in order to serve as fast as possible, without waste and reducing costs.

This methodology has already been implemented in Paraná as described by Anacleto and Negrelle (2019) who says that in Paraná it is common for flower retailers to form purchasing groups, and these groups are made up of 3 to 5 retailers, despite being competitors, they are partners, share freight and operate costs together at Veiling in Holambra. This practice promotes the reduction of weekly operating costs and they can buy flowers based on the market in the real time, which virtually eliminates the rate of flower disposal. 
The partnership among retailers and producers may be an important alternative to face the crisis resulting from the New Coronavirus, Bornancin (2018) describes that orientation of the retailers to the flower producers can create a collaborative environment, increasing the production efficiency in the field and consumption satisfaction levels, strengthening the flower production chain and at the same time reducing costs and avoiding losses on both sides. The partnership among retailers and regional producers in addition to avoiding losses and costs with long trips, it can also reduce the exposure on both sides to the virus.

It was observed that it is essential to analyze the restructuring and adaptation measures of flower shops in times of crisis. The unstable scenario that was formed in the pandemic crisis is harmful to companies and immediate solutions are not always able to adequately cover the necessary decisions, so the ability to adaptation is essential. However, as well as in regular periods, in crisis periods managers need to adopt differentiated strategies, so that when the resumption occurs, it is considered new forms of trade and the right restructuring in order to face the adversity of this period. After the change of this crisis scenario, new learning had taken place and new forms of relationship with costumers was established, not only economically viable, but also long-lasting.

\section{Conclusions}

The Covid-19 pandemic, which was established in the wide world, brought with it a serious economic crisis, making people to consume and search for essential products, instead of floriculture products, which are often labeled as superfluous. In relation to the preparation to face the pandemic period, a significant part of the interviewees ( $n=40 \%$ ) took some type of online training or course that could help them in their commercial activities, and among the most accessed courses, they reported courses on enterprise management and online sales. They also reported the use of e-commerce by social media as the most frequent action to restart the sales, and the most used Apps were WhatsApp and Instagram. They also mention other actions to face the pandemic crisis such as discount on purchases, free delivery and marketing in the neighborhoods.

During the pandemic, the floriculture sector was greatly affected, from production systems in the countryside to the removal of consumers from stores and flower shops, creating a disconnection between all sectors of the production chain. However, in this period, the retail trade could assume responsibility for the interlocution between producers and consumers, since in a short term the solution to this problem is not evident.

In this context, it was concluded that a governance model led by retail trade, could result in a recovery plan and guide both consumers and producers, in order to promote the continuity of flows with safety, prophylaxis and ensuring that the sector continue to maintain the jobs and income of thousands people in Brazil.
Although it is difficult to make an assertive prognosis about the crisis experienced, for the flower sector to overcome these fears it is essential to have an orientation towards the market and the retail trade within the production chain, as this can facilitate for better understanding of the conditions of the flower trade and the diagnosis of the crisis that is still changing.

Among the possible complementary actions to face the decline in sales in the quarantine period, which may have effects on the retail trade, it could be mention the offer of online courses aimed at local customers, the adoption of the Just In Time methodology which foresee partnership with local producers in order to reduce inventory and price, and the organization of collective purchasing groups in order to bargain prices with wholesalers and also reduce transportation and operational costs at Veiling in Holambra.

\section{Author Contribution}

AA and LS: Adviser of work, analysis and interpretation of data, critical review of the article, preparation and writing of the article, approval of the final version of the article. APAB and SHCM: research idea, elaboration of field questionnaire, field interviews with retailers, field analysis, data collection and analysis, interpretation, preparation and writing of the article.

\section{Acknowledgments}

The authors would like to thanks to Araucária Foundation for research funding.

\section{References}

ABILIO, L.C. Uberização: a era do trabalhador just-intime? Estudos avançados, v.34, n.98, p.111-126, 2020.

ANACLETO, A.; PRAZERES, A.S.G. Novo Coronavírus (COVID-19) e a crise econômica: impactos nas pequenas empresas. Revista Tecnologia e Sociedade, v.16, n.43, p.169-175, 2020. DOI: http://dx.doi.org/10.3895/rts. v16n43.12093

ANACLETO, A.; NEGRELLE, R.R.B. Bromeliads supply chain of Paraná State-Brazil. International Journal of Advanced Engineering Research and Science, v.6, n.2, p.1-12, 2019. DOI: https://dx.doi.org/10.22161/ijaers.6.2.1

BEZERRA, A.C.V.; SILVA, C.E.M.D.; SOARES, F.R.G.; SILVA, J.A.M. Fatores associados ao comportamento da população durante o isolamento social na pandemia de COVID-19. Ciência \& Saúde Coletiva, v.25, p.24112421, 2020.

BORNANCIN, A.P.A. Perfil e comportamento do consumidor de bromélias: orientação a produção rural. Revista Brasileira de Planejamento e Desenvolvimento, v.7, n.1, p.51-66, 2018. DOI: http:// dx.doi.org/10.3895/rbpd.v7n1.7055 
CRODA, J.H.R.; GARCIA, L.P. Resposta imediata da Vigilância em Saúde à epidemia da COVID-19. Epidemiologia e Serviços de Saúde, n.29, n.1, p.1, 2020. DOI: http://dx.doi.org/10.5123/S167949742020000100021

KOMATSU, B.K.; MENEZES-FILHO, N. Simulações de impactos da COVID-19 e da renda básica emergencial sobre o desemprego, renda, pobreza e desigualdade. São Paulo: Policy Paper, 2020. 31p.

FEITOSA, V.A.; CABRA, S.A.A.O.; ALENCAR, M.C.B.; UCHOA, S.A.O; SILVA H.M.L. A horticultura como instrumento de terapia e inclusão psicossocial. Revista Verde, v.9, n.5, p.7-11, 2014.

GUARIZZO, M. Mercado de flores amarga prejuízo milionário. $\mathrm{CBN}$. Available at: https://portalcbncampinas. com.br/2020/04/com-prejuizo-milionario-mercado-deflores-pede-mudancas-ao-governo. Accessed on: June $1^{\text {st }}$ 2020

GUIMARAES, L.F.A.; FALSARELLA, O.M. Uma análise da metodologia Just-In-Time e do sistema Kanban de produção sob o enfoque da ciência da informação. Perspectivas em Ciência da Informação, v.13, n.2, p.130-147, 2008.
JUNQUEIRA, A.H.; PEETZ, M. Brazilian consumption of flowers and ornamental plants: habits, practices and trends. Ornamental Horticulture, v.23, n.2, p.178-184, 2017. DOI: http://dx.doi.org/10.14295/oh.v23i2.1070

MINISTÉRIO DA SAÚDE. Painel Corona Vírus. Available at: <https://covid.saude.gov.br/>. Accessed on: May $23^{\text {th }}, 2020$.

AQUINO, E.M.; SILVEIRA, I.H.; PESCARINI, J.M.; AQUINO, R.; SOUZA-FILHO, J.A.D. Medidas de distanciamento social no controle da pandemia de COVID-19: potenciais impactos e desafios no Brasil. Ciência \& Saúde Coletiva, v.25, p.2423-2446, 2020.

OMS - ORGANIZAÇÃO MUNDIAL DA SAÚDE. Coronavirus disease (COVID-19) Pandemic. Available at: < https://www.who.int/emergencies/diseases/novelcoronavirus-2019>. Accessed on: June 1st, 2020.

TONELLI, M.J.; ZAMBALDI, F. Pesquisa em tempos de pandemia. Revista de Administração de Empresas, v.60, n.2, p.82-83, 2020.

VERGARA, S.C. Métodos de pesquisa em Administração, 6ed. Rio de Janeiro: Atlas, 2015. 292p. 